\title{
NONINVASIVE EVALUATION OF CARDIOVASCULAR EFFECTS OF PREOPERATIVE SEDATION IN CHILDREN
}

\author{
Herbert T. Maguire, George E. Webb, Allan H. Rees, and John B. Gattinella
}

PATIENTS coming for surgical procedures should be free of fear and apprehension with minimum depression of their vital functions of respiration and circulation. These goals have been approached in one of two ways. The first invokes psychological preparation and entails an extensive preoperative visit to answer the patient's questions and explain anticipated procedures. This approach will hopefully lessen the patient's anxiety and allay his fears of the unknown. These can be supplemented with the use of pharmacologic agents for premedication. These drugs may or may not exhibit their predicted action. Occasionally the action of the medication prescribed may prove of little benefit to the patient, or often the effect may be more depressing to the vital functions than is desired.

Agents administered by rectum have the advantage of involving the use of neither mask nor needle. Most children under five or six years of age do not object to the passage of a rectal tube. Children between the ages of one and three years may be considered the most excitable and best suited for rectal premedication techniques. Methohexitone has been reported to be a suitable agent for rectal administration to children. ${ }^{1.2}$

Innovar ${ }^{\mathbb{B}}$ is a combination of droperidol, a potent tranquillizer of the butyrophenone group. plus the narcotic fentanyl, a derivative of meperidine, in a 50:1 mixture. The term neurolept analgesia has been applied to the use of Innovar because it produces a state of tranquillization and intense analgesia with little hypnosis. This drug combination has found its main use during the anaesthetic period as part of a "balanced" general anaesthetic technique, or as an adjunct during regional anaesthesia. Some inter-

Herbert T. Maguire, M.D., Assistant Professor, Department of Anesthesiology, University of Louisville School of Medicine; George E. Webb, M.D., Professor, Department of Anesthesiology, University of Louisville School of Medicine; Allan H. Rees, M.D., Assistant Professor, Department of Pediatrics, University of Louisville School of Medicine: John B. Gattinella, Chief Echo Technical Director, Norton-Children's Hospitals, Inc. est has been aroused in its use for preoperative medication for patients to be subjected to various anaesthetic techniques. ${ }^{3}$ Information regarding the use of Innovar ${ }^{\text {Bd }}$ for premedication in children is limited. ${ }^{4}$

This study was undertaken to evaluate the effects of rectal methohexitone or intramuscular Innovar ${ }^{(\otimes)}$ on cardiovascular haemodynamics in paediatric patients, using echocardiographic techniques. Ultrasound cardiography, or echocardiography, is a new and useful tool for the noninvasive evaluation of cardiac anatomy and physiology.,6 This technique relies upon the physical properties of ultrasound, which is acoustic energy propagated at frequencies in excess of one million cycles per second. Transducers are available that can pulse ultrasonic waves a minute fraction of the time (less than 1 per cent) and act as a receiver the remainder of the time. The ultrasonic energy pulsed through the body is partly reflected as echoes at the interface between two adjacent biological tissues. These returning echoes are sensed and transmitted into a high-speed oscilloscope and organized with respect to time to illustrate the movement of the individual reflector interface.

The ability to calculate left ventricular volumes and the ejection fraction during the cardiac cycle permits the evaluation of left ventricular function of the heart. The left ventricle approximates an ellipsoidal configuration. Based on this fact, left ventricular volumes at end-systole and enddiastole can be estimated by measuring the major and minor axes of the left ventricle directly from the anteroposterior and lateral projections of the left ventriculogram and then applying the formula for calculation of volume of an ellipsoid..$^{7-9}$ Until recently these measurements were only obtainable from angiographic studies performed during cardiac catheterization. It is now possible to estimate left ventricular volumes and ventricular function parameters noninvasively using echocardiographic left ventricular dimension measurements. ${ }^{10-14}$ These measurements have been shown to have an excellent correlation with those obtained by angiographic techniques. ${ }^{15}$ 
TABLE I

Patient Characteristics

\begin{tabular}{|c|c|c|c|c|c|c|c|}
\hline & \multirow{2}{*}{$\begin{array}{c}\text { Number of } \\
\text { patients }\end{array}$} & \multicolumn{2}{|c|}{ Age (yrs) } & \multicolumn{2}{|c|}{ Wt $(\mathrm{kg})$} & \multicolumn{2}{|c|}{ Sex } \\
\hline & & Mean & Range & Mean & Range & Male & Female \\
\hline Group I & 11 & 3.83 & $0.25-6$ & 14.6 & $6.3-20$ & 7 & 4 \\
\hline Group II & 11 & 7.58 & $2.25-14$ & 29.3 & $12.7-51.3$ & 6 & 5 \\
\hline
\end{tabular}

\section{METHOD AND MATERIALS}

Twenty-two children scheduled for elective operations and who were rated ASA physical status I were selected for the study. They were divided into two groups. Group I was premedicated rectally with a 10 per cent methohexitone solution using $22 \mathrm{mg} \cdot \mathrm{kg}(10 \mathrm{mg} \cdot \mathrm{lb})$. Group II received Innovar intramuscularly $0.03 \mathrm{ml} \cdot \mathrm{kg}$ body weight (droperidol $75 \mu \mathrm{g} \cdot \mathrm{kg}$, fentanyl 1.5 $\mu \mathrm{g} \cdot \mathrm{kg}$ ).

The study was performed in the paediatric preoperative holding area. The procedure was explained to the parents and written consent was obtained. Parents were allowed to be present during the entire study. All patients were supine during the examination.

The age range for Group I (methohexitone group) was from three months to 6 years (mean age $=3.83$ ) (Table I). Seven were males and four females. Group II (Innovar ${ }^{\text {(B) }}$ group) ages ranged from 2.25 years to 14 years (mean age 7.58 ). Six were males and five females.

Blood pressure, pulse, respiration, and echocardiogram were recorded on all patients before and after the premedication was administered.

Echocardiographic evaluation was done with a Smith-Kline Ekoline 20 ultrasonoscope interfaced with a Honeywell fiberoptic strip chart recorder. A $2.25 \mathrm{MHz}$ focused $(5 \mathrm{~cm})$ transducer with an active crystal diameter of 0.5 inch was employed. The children were studied in the supine position with the transducer positioned along the left sternal border of that intercostal space from which a strong mitral valve echo was visualized. This is usually the fourth interspace but could be from the third to the fifth. The transducer was oriented perpendicular to the chest wall with slight medial, but no other, angulation. ${ }^{16}$ From this position the transducer was slowly tilted in an inferior and lateral direction until the echoes of the mitral valve were replaced by those of the chordae tendinae. The echogram was recorded at this level after minor adjustments

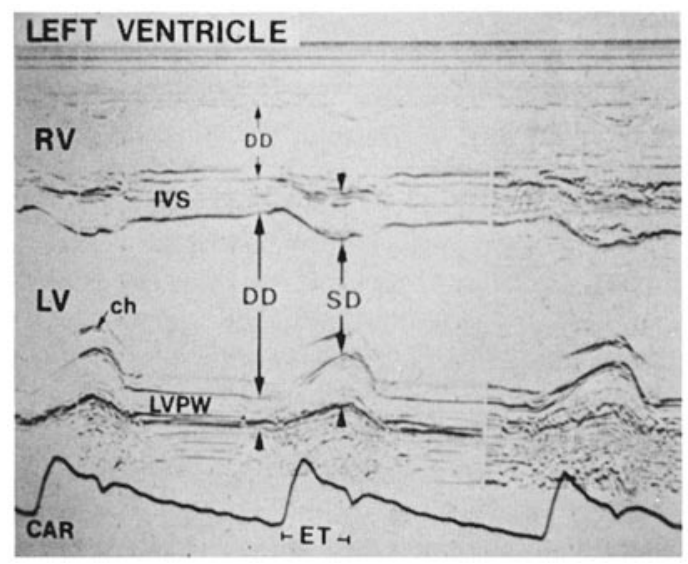

Figure 1 M-mode scan of the left ventricle (LV) showing the "standard area" for measurement of LV dimensions. $\mathrm{RV}=$ right ventricular cavity; IVS $=$ interventricular septum; $\mathrm{LV}=$ left ventricular cavity; $\mathrm{CH}$ $=$ chordae tendineae; DD $=$ left ventricular short axis dimension at end-diastole; $\mathrm{SD}=$ left ventricular short axis dimension at end-systole; $\mathrm{LVPW}=$ left ventricular posterior wall; $\mathrm{CAR}=$ external carotid artery pulse tracing; $\mathrm{ET}=$ ejection time.

in transducer angulation and/or gain control to provide optimal visualization of the endocardial echoes from both the posterior left ventricular wall and the left side of the interventricular septum.

The left ventricular end-diastolic dimension (Dd) was measured as the vertical distance between the left septal echo and the left ventricular endocardial echo at the onset of the QRS complex of the electrocardiogram. The left ventricular end-systolic dimension (Ds) was measured at the point of maximal approximation of the interventricular septum and the posterior left ventricular wall (Figure 1). Using these echocardiographic dimensions, the percent shortening of the echocardiographic minor dimension of the left ventricle $(\% \Delta \mathrm{D})$ was calculated as: ${ }^{10}$

$\% \Delta \mathrm{D}$ (per cent change in dimension)

$$
=(\text { Dd-Ds }) \times 100 / \mathrm{Dd}
$$

Statistical analysis was by Student's t-test on 
TABLE II

Summary of HaEmodynamic, Respiratory and EchoCARDIOGRAPHIC DATA

Mean \pm S.E.

\begin{tabular}{|c|c|c|}
\hline & $\begin{array}{c}\text { Group I } \\
\text { Methohexitone }\end{array}$ & $\begin{array}{l}\text { Group II } \\
\text { Innovar }\end{array}$ \\
\hline \multicolumn{3}{|l|}{ Dd } \\
\hline Before & $3.1 \pm 0.4$ & $3.2 \pm 0.5$ \\
\hline After & $2.7 \pm 0.5$ & $3.0 \pm 0.5$ \\
\hline \multicolumn{3}{|l|}{ Ds } \\
\hline Before & $2.1 \pm 0.4$ & $2.0 \pm 0.4$ \\
\hline After & $1.9 \pm 0.3$ & $2.0 \pm 0.5$ \\
\hline \multicolumn{3}{|l|}{$\% \Delta D$} \\
\hline Before & $37 \pm 6$ & $40 \pm 11$ \\
\hline After & $34 \pm 9$ & $39 \pm 13$ \\
\hline \multicolumn{3}{|c|}{ Blood pressure } \\
\hline \multicolumn{3}{|c|}{ Systolic } \\
\hline Before & $96 \pm 12$ & $104 \pm 15$ \\
\hline After & $93 \pm 12$ & $104 \pm 16$ \\
\hline \multicolumn{3}{|l|}{ Diastolic } \\
\hline Before & $60 \pm 14$ & $65 \pm 12$ \\
\hline After & $59 \pm 13$ & $58 \pm 8$ \\
\hline \multicolumn{3}{|l|}{ Pulse } \\
\hline Before & $100 \pm 22$ & $92 \pm 21$ \\
\hline After & $111 \pm 14$ & $88 \pm 20$ \\
\hline \multicolumn{3}{|c|}{ Respiratory rate } \\
\hline Before & $24 \pm 3$ & $20 \pm 4$ \\
\hline After & $24 \pm 3$ & $17 \pm 4$ \\
\hline
\end{tabular}

Dd, left ventricular end-diastolic dimension; Ds, left ventricular end-systolic dimension; $\% \Delta \mathrm{D}$, percent shortening of minor axis of left ventricular dimension during systole.

paired values during the study for each cardiovascular variable compared with control values.

\section{RESULTS}

Haemodynamic and echocardiographic data for the two groups of patients are listed in Table II. Statistical analyses are given for the echocardiographic measurements, shortening fraction calculation, blood pressure, heart rate and respiratory rate.

No significant changes were noted in systolic or diastolic blood pressure after the administration of rectal methohexitone or intramuscular Innovar ${ }^{\text {iti. }}$. No statistically significant changes in heart rate were detected in the two groups of patients. Although the respiratory rate following Innovar ${ }^{\text {E }}$ was reduced, the difference was not statistically significant.

The analysis of the echocardiographic data presented in Table II shows no statistically significant difference in the calculated shortening fraction for the two groups of patients. This was also reflected by no significant changes in the end-diastolic or end-systolic dimensions observed between the two groups. These findings are consistent with the presence of adequate myocardial contractility in the two groups of children studied.

\section{Discussion}

In this study, we evaluated the cardiovascular haemodynamic effects of two methods of preoperative sedation used in paediatric anaesthesia. The effectiveness of these drugs as premedicants has been reported previously. ${ }^{2-4}$ However, in the previous studies the only cardiovascular parameters reported were systolic blood pressure and pulse rate.

The difficulties involved in measuring more sophisticated haemodynamic parameters with invasive techniques in unsedated paediatric patients are nearly insurmountable. Our use of echocardiographic techniques allowed measurement of changes in left ventricular performance. This noninvasive measurement was well 
accepted by the children. It was not painful and was done in the presence of a child's parents. This permitted stable and reproducible baseline values. This technique gave us the opportunity to measure cardiovascular effects of drugs in paediatric patients without resorting to invasive procedures.

Our results showed both methods of premedication in children to be free of significant cardiovascular effects. No changes in left ventricular performance could be demonstrated.

Budd, Dornette, Wright ${ }^{2}$ reported the effectiveness of rectal methohexitone for basal narcosis; however, no measurement of changes in circulation was made. Our study demonstrates no significant changes at the doses used, which were $22 \mathrm{mg} \cdot \mathrm{kg}$ of methohexitone and $0.03 \mathrm{ml} \cdot \mathrm{kg}$ of Innovar ${ }^{\sqrt{8}}$.

Mandelstam ${ }^{4}$ used Innovar ${ }^{\AA}$ for paediatric premedication between three and 12 years of age and found it to be satisfactory, with minimal effects on systolic blood pressure and pulse. Stephen ${ }^{17}$ studied droperidol as a premedicant and could demonstrate no significant changes in pulse rate or systolic and diastolic blood pressure. Other workers investigating the cardiovascular effects of Innovar ${ }^{\sqrt{8}}$ during operation found no evidence of myocardial depression. ${ }^{18.19}$ Our study substantiated the findings that Innovar ${ }^{\text {tit }}$ $(0.03 \mathrm{ml} \cdot \mathrm{kg})$ as premedication has no adverse effects on left ventricular haemodynamics. Respiratory rate changes were statistically insignificant in patients who received either rectal methohexitone or Innovar ${ }^{\bar{B}}$ intramuscularly. Since no measurements of minute ventilation were done, no comment can be made on the respiratory effect of these drugs.

Theoretically the response to rectal administration of methohexitone may be unpredictable due to the variability of faecal $\mathrm{pH}$ and site of absorption. Venous blood from the proximal rectum flows to the liver through the portal system while that from the lower rectum reaches the general circulation through the inferior vena cava. ${ }^{20}$ We had a very consistent effect with both premedicant drugs.

\section{SUMMARY}

The cardiovascular effects of two premedication regimes used in paediatric anaesthesia were studied. Eleven patients received rectal methohexitone $(22 \mathrm{mg} \cdot \mathrm{kg}$ ) and 11 patients received intramuscular Innovar ${ }^{\circledR}(0.03 \mathrm{ml} \cdot \mathrm{kg})$. The effect of these drugs on ventricular function was evaluated by measuring the shortening of the left ventricular minor dimension by echocardiography. No significant changes in this dimension, blood pressure, heart rate or respiratory rate were demonstrated with either drug.

Both rectal methohexitone and intramuscular Innovar were shown to have minimal cardiovascular effects when used as preoperative sedation in paediatric patients. Echocardiography proved to be a valuable technique for the noninvasive evaluation of drug effects on myocardial contractility in children.

\section{RÉSUMÉ}

Nous avons étudié les effets cardiovasculaires de deux prémédications utilisées en pédiatrie. Onze enfants ont reçu du méthohexital par voie rectale ( $22 \mathrm{mg} / \mathrm{kilo}$ ) et 11 autres ont reçu par voie intra-musculaire de l'Innovar ${ }^{(E)}$, à raison de $0.03 \mathrm{ml} / \mathrm{kg}$. L'effet de ces médicaments sur la fonction ventriculaire a été évalué par la mesure du raccourcissement du diamètre transverse du ventricule gauche à l'échocardiographie.

On n'a observé aucun changement significatif de ce diamètre, de la pression artérielle, des fréquences cardiaques et respiratoires, à la suite de l'administration de l'une ou de l'autre des prémédications étudiées. Le méthohexital rectal et l'Innovar ${ }^{(i)}$ intra-musculaire utilisés comme sédatifs pré-opératoires en pédiatrie ont des effets dépresseurs minimes sur le système cardiovasculaire. L'échocardiographie s'est avérée une technique non-invasive utile pour l'étude des effets des médicaments sur la contractilité myocardique chez l'enfant.

\section{REFERENCES}

1. Coleman, J. \& Green, R.A. Methohexital, a short-acting barbiturate. Anaesthesia 15: 411 (1960).

2. Budd, D.C., Dornette, W.H.L., \& Wright, J.F. Methohexital for rectal basal narcosis. Anesth. Analg. 44: 222-225 (March-April, 1965).

3. Catton, D.V. \& Brown, R.A. Premedication with fentanyl and droperidol. Canad. Anaesth. Soc. J. 16: 72-76 (Jan., 1969).

4. Mandelstam, J.P. An inquiry into the use of Innovar for pediatric premedication. Anesth. Analg. 49: 746-749 (Sept.-Oct., 1970).

5. Meyer, R.A. \& Kaplan, S. Non-invasive techniques in cardiovascular disease. Prog. Cardiovasc. Dis. 15: 341 (1973).

6. Sahn, D.J., Allen, H.D., Goldberg, S.J., SolINGer, R., \& Meyer, R.A. Pediatric echocardiography: a review of its clinical utility. J. Pediatrics 87: 335-352 (Sept. 1975). 
7. Dodge, H.T., Sandler, H.. Ballew, D.W.. \& LORD, J.D. The use of diplane angiocardiography for the measurements of left ventricular volume in man. Amer. Heart J. 69: 762 (1960).

8. Graham, T.P., JR., Lewis, B.M., Jarmakani, M.M. CAnent, R.V., \& CAPP, M.P. Left heart volume and mass quantification in children with left ventricular pressure overload. Circulation 41: 203 (1970).

9. Jarmakani, M.M.. Edwards, S.B., Spach, M.S., Canent, R.V., JR., CaPP, M.P., Hagan, M.J., BARR, R.C., \& JAIN, V. Left ventricular pressure-volume characteristics in congenital heart disease. Circulation 37: 879 (1968).

10. Meyer, R.A., Stockert, J., \& Kaplan, S. Echocardiographic determinations of left ventricular volumes in pediatric patients. Circulation 5I: 297 (1975).

11. Paraskos, J.A., Grossman, W., Saltz, S., DALEN, J.E., \& DeXTER, L. A noninvasive technique for the determination of velocity of circumferential fiber shortening in man. Circ. Res. 29: 610 (1971).

12. Quinones, M.A.. GaAsch, W.. \& Alexander, J.K. Echocardiographic assessment of left ventricular function, with special reference to normalized velocities. Circulation 50: 42 (1974).

13. Rees, A.H., Stefadouros, M.A., Strong, W.B., Miller, M.D., Gilman, P., Rigby, J.A., \&
McFARLANE. J. Left ventricular performance in children with homozygous sickle cell anemia. Brit. Heart $\mathbf{J}$., in press.

14. Fortuin, N.J., Hood, W.F., JR., Craige, F. Evaluation of left ventricular function by echocardiography. Circulation 46: 26 (1972).

15. Fortuin, N.J., Hood, W.F., JR., Sherman, M.E. \& Craige, E. Determination of left ventricular volumes by ultrasound. Circulation 44:575 (1971).

16. Popp, R.L.. Filly, K., Brown, O.R., \& HarrisoN, D.C. Effect of transducer placement on echocardiographic measurement of left ventricular dimensions. Am. J. Cardiol. 35: 537 (1975).

17. Stephen, C.R. Premedication with Droperidol. A double blind study. Canad. Anaesth. Soc. J. 17: 403 (1970).

18. Ferrari, H.A., Gorsen, R.J., Talton, I.H., Carrent, R.. \& GoOdrich, J.K. The action of Droperidol and Fentanyl on cardiac output and related hemodynamic parameters. Southern Med. J. 67:49 (1974).

19. Graves, C.L., Downs, N.H., \& Browe, A.B. Cardiovascular effects of minimal analgesic quantities of Innovar , fentanyl and droperidol in man. Anes. Analg. 54: 15 (1975).

20. Woodburne, R.T. Essentials of Human Anatomy. New York, Oxford University Press (1957), p. 149. 